\title{
Lazunaren akuikultura jasangarria lortzeko aurrerapausoak
}

\author{
(First steps in sustainable mullet aquaculture development)
}

\author{
Ager Ortiz Aginagalde*1, Nadia Conlledo Gorrotxategi ${ }^{1}$, Xabier Lekube Iturrioz ${ }^{2}$, \\ Urtzi Izagirre Aramaiona ${ }^{2}$
}

${ }^{1}$ Kardala LHII Akuikultura Eskola, Portua z/g (Kofradia eraikina). 20830 Mutriku, Euskal Herria

${ }^{2}$ CBET Research Group,

Research Centre for Experimental Marine Biology and Biotechnology (PIE-UPV/EHU), Euskal Herriko Unibertsitatea (UPV/EHU), Plentzia, Euskal Herria

\begin{abstract}
LABURPENA: Gaur egungo bizimoduaren beharretara moldatzeko bidean, jarduera ekonomiko jasangarrietara jotzea du helburu Europar Batasunak, baita akuikultura arloan ere. Ildo horri eutsiz, Eusko Jaurlaritzaren Arrantza eta Akuikultura zuzendaritzak, Itsas eta Arrantzarako Europako Funtsaren bidez lagunduta, eta Euskal Herriko erakunde ezberdinen (GAIKER-IK4, PiE-EHU, KARDALA LHII) elkarlanarekin, AKURA proiektua jarri zuen martxan 2017. urte amaieran. Akuikultura-sektorean garapen jasangarria bultzatzeko asmoen barruan, bertakoa den arrain-espezie berritzailea aukeratu da ikerketen ahaleginak zentratzeko: lazuna, hain zuzen. Hazkuntza azkarreko arraina da, erresistentea, autoktonoa eta orojalea. Azken ezaugarri honek gaur egun industrian gehien hazten diren espezieetatik desberdintzen du, haragijaleetatik alegia. Lazunek, animali jatorria duten proteinekiko dependentzia baxuagoa dutenez, arrain irinekiko existitzen den dependentzia murriztea ahalbidetzen dute, eta, bide batez, dieta jasangarriagoak eta moldagarriagoak egitea. Beraz, lazunen hazkuntza-sistema optimizatzearekin batera, dieta espezifiko eta aberastuak formulatzea izango da helburu nagusietako bat. Ildo horretatik ikusi da proteina, gantz eta karbohidratoen arteko oreka nutrizionala lortzeko oraindik ikerketen beharra dagoela. Bizi-zikloa gatibutasunean ixtea botila-lepo moduan planteatzen den arren, lehenengo erruteak lortu dira eta hasierako hilkortasun-fase kritikoa igaro ondoren hazkuntza azkarra izatea lortu da. Ikerketa-proiektu honek lazunaren akuikultura jasangarria lortzeko lehenengo urratsak ezartzen ditu. Proiektua martxan dago, eta, oraindik erronka asko geratzen diren arren, lazunak industriarako duen potentziala nabaria da.
\end{abstract}

HITZ GAKOAK: Akuikultura, Jasangarritasuna, Chelon labrosus, Mugil cephalus.

\begin{abstract}
In order to adapt to the needs of today's life, the European Union aims to contribute to sustainable economic activities including aquaculture. In line with this, at the end of 2017 the Basque Government's Fisheries and Aquaculture Directorate, throughout the European Maritime and Fisheries funds, supports the AKURA project which involves different institutions in the Basque Country (GAIKER-IK4, PiE-UPV/EHU, KARDALA LHII). In order to promote sustainable development of the aquaculture sector, an innovative native fish species (mullets) has been chosen to focus on research efforts. It is a fast-growing fish, resistant, indigenous and omnivore. This latter characteristic differentiates this fish species from the most widely grown species in the industry today which are carnivores. Mullets, have low dependence on animal protein, for that reason it can be a good candidate to reduce the use on fish flour and advance on sustainable aquaculture. Therefore, together with the optimization of the mullets growing and breeding system, formulating specific and enriched diets will be one of the main goals in the aquaculture of this species. To this respect, it has been observed that an appropriate nutritional balance between protein, fat and carbohydrates is still needed. Closing the life cycle is known to be a bottleneck in aquaculture. In the present work the first breeding have been achieved and rapid growth has been observed after a initial mortality at critical stages. This research project sets out the first steps towards a sustainable aquaculture of mullets in the Basque Country. Although the project is underway and many challenges remain, the potential for the mullets in aquaculture industry is noticeable.
\end{abstract}

KEYWORDS: Aquaculture, Sustanaibility, Chelon labrosus, Mugil cephalus.

* Harremanetan jartzeko / Corresponding author: Ager Ortiz Aginagalde, Kardala LHII Akuikultura Eskola, Portua, z/g (Kofradia eraikina). 20830 Mutriku, Euskal Herria. - aortiz@kardalalhii.net - https://orcid.org/0000-0002-0206-672X.

Nola aipatu / How to cite: Ortiz Aginagalde; Ager; Conlledo Gorrotxategi, Nadia; Lekube Iturrioz, Xabier; Izagirre Aramaiona, Urtzi (2020). "Lazunaren akuikultura jasangarria lortzeko aurrerapausoak»; Ekaia, ale berezia 2020, 321-337. (https://doi.org/10.1387/ekaia.21078).

Jasoa: 02 iraila, 2019; Onartua: 25 azaroa, 2019

ISSN 0214-9001 - elSSN 2444-3255 / (c) 2020 UPV/EHU

Obra hau Creative Commons Atribución 4.0 Internacional-en

lizentziapean dago 
Ager Ortiz Aginagalde, Nadia Conlledo Gorrotxategi, Xabier Lekube Iturrioz, Urtzi Izagirre Aramaiona

\section{SARRERA}

Gaur egungo bizimodua eta kontsumo-joera aztertuta, etorkizunera begira, gizateriak sekulako erronka dauka XxI. mendearen erdirako $9.000 \mathrm{mi}-$ lioi pertsonakoa izango den biztanleria elikatzeko. Egoera horretan, gizartea kontsumo arduratsuaren bidean jartzea, baliabide naturalak zaintzea, arrantza eta nekazaritza jasangarriak sustatzea beharrezkoak dira lehenbailehen. Aurrekoarekin lotuta, geroz eta gizarte populatuago bat elikatzeko arrantza bidezko itsasoen gehiegizko ustiapena dela-eta, akuikultura bultzatzea ezinbestekotzat jotzen dute erakundeek, eta, horretarako, maila ezberdinetako esfortzuak egiten ari dira [1].

Nazio Batuen Elikadura eta Nekazaritza Erakundearen (FAO) arabera [2], akuikultura arrain, molusku, krustazeo, ur-landare eta beste zenbait ur-organismoren hazkuntzari deritzo. Lehorrean ezagutzen ditugun nekazaritzaren eta abeltzaintzaren antzeko jarduera da. Akuikultura harrapaketa bidezkoa izan daiteke (animalia edo landarea harrapatu edo jaso eta ondoren tamaina komertzialeraino haztea), edo produkzio bidezkoa (organismoaren bizi-ziklo osoa gatibutasunean egiten denean), eta ekoizpen horrek organismoaren banako edo korporazio baten bidezko jabetza dakar.

Hasieran aipaturiko etorkizun iluna ekiditeko, Nazio Batuek Garapen Jasangarrirako 2030 Agenda ezarri dute, beharrezko esfortzuak egin daitezen bide honetan. Haren leloa «Gure mundua eraldatu» da, eta garapen jasangarrirako 17 helburu (GJHak, Ingelesez Sustainable Development Goals) hartzen ditu, inor baztertuko ez duen bide jasangarri eta indartsu batean mundua jarriko duen ikuspegi paregabe, eraldatzaile eta integratzailea erakutsiz [3].

Munduko estatu guztiei dagokie 2030 Agendari jarraitzea. Garapen jasangarriaren 3 zutabeak (soziala, anbientala eta ekonomikoa) elkartzen ditu, eta herrialdeentzat, Nazio Batuentzat eta gobernuarteko, gizarte zibileko zein bestelako erakundeentzat gida moduan jokatu behar du. Lehen aipaturiko GJHek orain arte Nazio Batuen Elikadura eta Nekazaritzarako Erakundeak (FAO) akuikulturari emandako garrantzia areagotu egiten dute. Horrek akuikulturaren garapen jasangarrirako planifikazioa eta kudeaketa zein politika ezberdinen hobekuntza erraztuko du. Akuikulturarekin lotura duten GJHen artean, GJH 1 (pobrezia desagerraraztea), GJH 2 (gosea desagerraraztea), GJH 12 (ekoizpena eta kontsumoa), GHJ 13 (klima-aldaketa), GJH 14 (itsas baliabideak eta ekosistemak) eta GJH 15 (bioaniztasuna) aurkitu ditzakegu [3].

Europar Batasunean, ingurumen- eta gizarte-politiketan aitzindaria izanik, GJHak erdiesteko bidean, ekintza ezberdinak garatu dira. Horren adibide modura, Europar Batasunak bultzaturiko «Diversify» proiektuak akuikultura-industria zabaltzeko ahalmena izan dezaketen hainbat arrain- 
espezie berritzaile hautatu ditu [4]. Espezie horiek, batetik, izan ditzaketen gaitasun biologiko zein ekonomikoengatik hautatu dira, eta, bestetik, Europako eremu geografiko guztia barnean hartzeko, akuikultura mota ezberdinak suspertzeko, eta tokian tokiko espezie autoktonoen hazkuntza bultzatzeko. Proiektuak, azkenik, espezie horietako bakoitzaren hazkuntzak dituen botila-lepoak identifikatu eta horiek konpontzen lan egiteko lehen urratsak proposatzen ditu [4], bide batez balio erantsi handiko produktuak sortzeko xedearekin.

Eusko Jaurlaritza ere, Europar Batasunaren ildo estrategikoari jarraituz, akuikultura bultzatzeko pausoak ematen ari da azkenaldian. Horren froga dira 2014-2020 aldirako Akuikulturaren Garapenerako Plan Estrategikoaren barnean Itsas eta Arrantzarako Europako Funtsari (EMFF 2014-2020) buruzko arautegiak lehentasunezko gai-ardatzetan sartuta dauden helburuak, hala nola baliabide naturalak eta ingurumena zaintzea edo akuikulturaren jasangarritasuna zein lehiakortasuna bultzatzea [5].

Horrekin guztiarekin lotuta, Eusko Jaurlaritzaren Arrantza eta Akuikultura zuzendaritzak, Itsas eta Arrantzarako Europako Funtsaren bidez lagunduta, eta Euskal Herriko zenbait erakunderen (GAIKER-IK4, PiE-EHU, KARDALA LHII) elkarlanarekin, AKURA proiektua jarri zen martxan 2017. urtearen amaieran.

\section{AKURA ETA AKUIKULTURA JASANGARRIA}

\subsection{Hitz gutxitan}

Balio erantsi handiko amaierako produktua izango duen eta hazkuntzamodu ezberdinetan eta espezie berrietan (lazuna) oinarrituta dagoen akuikulturarako proiektu jasangarri baten garapena da AKURA.

\subsection{Helburu nagusia}

AKURA proiektuak, Europako mailako gomendioei jarraituz, espezie berritzaile bat aukeratu du, gure inguruko akuikultura-industriaren garapenari bultzada bat emateko asmoarekin. Jasangarritasunaren ildotik jarraitzeko konpromisoa duen proiektua da, eta, horretarako, Europako Batasunak espezie horren (lazuna) inguruan jaso duen ezagutza handitzea da helburua.

\subsection{Espezie-aukeraketa}

AKURA proiektuaren barruan espezien aukeraketa ez da zoriz egin; izan ere, «Diversify» proiektuak gomendatzen dituen espezieen barruan mugilidoen familian kokatuta dagoen Mugil cephalus espeziea aztertu da. 
Ager Ortiz Aginagalde, Nadia Conlledo Gorrotxategi, Xabier Lekube Iturrioz, Urtzi Izagirre Aramaiona

Mugilidoen familia barruko espezieek erakusten duten homogeneotasuna dela eta, familia barruko bi espezietan ardaztu da proiektua: Mugil cephalus eta Chelon labrosus espezietan, hain zuzen ere; alegia, aski ezagunak diren korrokoi edo lazunetan (hemendik aurrera lazuna). Antzekotasun handiko espezieak dira zentzu askotan, esperientziarik gabeko begientzat maiz bereizi ezinak izanik.

Lazunak, orokorrean, lohi-jale, iliofago edo detritu-jale moduan deskribatu dira, dieta sedimentu artean dagoen materia organikoan oinarritzen delako. Hala ere, ornogabe bentonikoz, hari-formako alga berdez, planktonaz eta esekiduran dagoen bestelako materia organikoz ere elikatzen dira. Ez dago beste arrain talderik mikrobentosarekiko lazunek duten menpekotasuna gainditzen dutenik, hori baitute dietaren osagairik nagusiena. Arrain itsastar belarjale gehienak alga mamitsuz, itsas belarrez, koral-itxurako algaz edo bestelako makroalgaz elikatzen dira, baina ez lazunek jaten dituzten sedimentuetan hazten diren organismo mikroskopikoez [6].

Azaldutako izaera orojalea da akuikulturarako aukeraketaren arrazoi nagusietako bat, pentsuen jasangarritasuna lortzeko alderdi interesgarriena, hain zuzen ere. Gainera, banaketa zabalekoak dira, eta alde epel zein tropikaletan itsasoko zein kostaldeko edozein uretan aurkitu ohi dira; gure kostaldean bereziki ugariak dira. Horrela, bertako espezie baten hazkuntza eta akuikulturako produktu interesgarria sustatzen dira.

Hori gutxi balitz, eurihalinoak eta euritermoak dira, hau da, gazitasun- zein tenperatura- tarte zabalak jasateko gai [6]. Hazkuntza-prozeduran arrain erresistenteak izatea ere abantaila handitzat jotzen da akuikultura produktuetan. Hazkuntza azkarreko arraintzat jotzeak ere aukera teorikoa ematen du industriari dagokionez prozesua ekonomikoki errentagarriagoa izateko. Tamalez, lazunek dituzten akuikulturarako abantaila teoriko horiek guztiak berretsi eta leundu behar dira. Lazunen akuikultura jasangarria eta produktiboa lortzeko, oraindik erronkaz jositako ikerketa gidatuak aurrera eraman behar dira, prozedura estandarizatu bat lortu arte.

\subsection{Erronkaz jositako proiektua}

AKURA proiektua erronkaz josita dagoen jakintza-alor anitzeko proiektua dela esan genezake. Alde batetik, ezagumendu biologikoen lorpena dago eta, bestetik, produktu berritzaile baten merkaturatze-helburuak:

\subsubsection{Prozedura estandarizatu bat sortzea lazunaren akuikulturarako}

Zenbait herrialdetan lazunak aspalditik hazten/loditzen dira, estuarioetan, modu estentsiboan edo multitrofikoan, gehienetan ur gezan edo gazi-gezan [7]. Kantauriko kostaldeak eskaintzen dituen baldintzetarako hazkuntza-aurrekaririk publikatuta ez dagoenez, ahalik eta datu gehien ja- 
sotzea da lehen pausoa prozesu industrial jasangarria baten estandarizazioa diseinatzeko eta optimizatzeko. Beste batzuen artean behar diren baldintzak ur gazia, lur barneko instalakuntza-osagarriak eta 13-25 bitarteko tenperaturak dira. Kalitatezko produktu bat sortzeko abagunea dugu, baina hori ikerketa arduradun baten oinarrituta egon behar da.

\subsubsection{Pentsuaren problematikari aurre egitea eta amaierako produktua aberasteko aukera}

Gure inguruan ezagutzen ditugun akuikultura-industriak ekoitzitako arrain gehienak haragijale hertsiak dira: esaterako, urraburua, erreboiloa, amuarraina edo lupia. Horrek, Europako Batasunak akuikultura jasangarria bultzatzen duen garai honetan, paradoxa garrantzitsu bat jartzen digu esku artean. Aipaturiko arrain horien nutrizio-eskakizunak asetzeko pentsuak arrain-irinekin zein olioekin formulatzen dira, eta produktu horiek gehienbat erauzketa-arrantzatik lortutako arrainetatik lortzen dira.

Akuikultura jasangarria baten esparruan, erauzketa-arrantzaren menpe egotea ulertezina da; beraz, funtsezko helburuetako batek itsasoaren gehiegizko ustiapena ekiditea izan behar du. Bestalde, arrain-irinen prezioen gorabehera handiek sektorearen egonkortasuna arriskuan jartzen du. Ildo horretatik, ikertzaile talde askok urteak daramatzate aukera jasangarriago eta merkeagoen bila. Aukera ezberdinen artean, irin-harren (Tenebrio molitor) [8] edo soldadu euli beltzen (Hermetia illucens) [9] edo gisako intsektuen proteinaz formulatutako pentsuak egongo lirateke, baita soja eta antzeko produktu begetalekin formulatutakoak ere [10].

Lazunak orojaleak izanda, bereziki helduaroan, pentsuetan animali proteinaren beharra asko jaisten denez, aipatutako pentsu berri horien guztiaren ustiapen potentziala oso altua da. Are gehiago, lazunek erakusten duten malgutasun horren barruan, elikadura produktu naturalekin aberasteak, azken produktuaren kalitateari nutrizio-balioa gehitu diezaioke. AKURA proiektuaren helburuetako bat pentsu osasuntsuagoak eta jasangarriagoak diseinatzea da. Horretarako, proiektuaren barruan behin oinarrizko pentsu bat erabakita dagoenean, hurrengo fase batean, pentsu horiek aberastea planifikatuta dago: adibidez, kate luzeko omega-3 eta horren gisako gantzazido osasungarriak dituzten mikroalgak erabiltzen dira (Nannocloropsis gaditana, esaterako) [11] arrainen muskuluan metatzea bultzatzeko asmoz. Giza kontsumorako onura argiak izango dituen akuikultura-produktua ekoiztea ahalbidetuko luke aberasketa horrek.2.4.3 Ziklo biologikoa gatibutasunean ixtea

Lazunaren akuikultura, orain arte, habitat -eremu luzeak behar dituen metodologia tradizional, produktibitate gutxikoan oinarritu da [7]. Ingurumenetik arrantzatzen diren indibiduo hasi berriak estentsiboki edo erdi-intentsiboki hazten dira padura-ingurumenetan. Arrainkumeak arrantza bidez 
Ager Ortiz Aginagalde, Nadia Conlledo Gorrotxategi, Xabier Lekube Iturrioz, Urtzi Izagirre Aramaiona

ez lortzeko bide bakarra lazunen bizi-ziklo osoa gatibutasunean lortzea da. Hau da, arrantza bidez lortutako sexualki helduak diren indibiduo ugaltzaileengandik arrautzak lortu eta berauen larbak hazteko baliabideak eta ezagutza lortzea. Gatibutasunean jaiotako arrain horiek ugaltzeko gai direnean eta bigarren belaunaldi bat lortzen den momentuan, itxitzat jotzen da bizizikloa [12]. Horrela, arrantzak sorraraz dezakeen presioa gutxituko litzateke.

Espezie horietan bereziki zaila suertatu da gatibutasuneko ugalketa, orain arte ezagutzera eman diren saiakeren emaitzen arabera. Ugalketarako beharrezkoak diren parametro zehatzak ezagutzen ez direlako gertatzen da hori. Behin ugalketaren baldintza orokorrak ezagutzen direnean, errutea eta bizi-zikloa merkatuaren beharretara moldatzeko aukera egongo da, prozesu osoa optimizatuz. [13]

\subsubsection{Akuikulturaren produktuen trazabilitatea eta segurtasuna bermatzeko erreminta garatzea}

Gaur egun, azken kontsumitzaileak erosten duen produktuaren gero eta ezagutza handiagoa exijitzen du. Badirudi gizarteak zentzu positiboan ikusten duela akuikulturak itsasoko produktuen merkatuari egiten dion ekarpena eta baita produktu horiek duten kalitate egonkorra ere, baina, beste alde batetik, pertzepzioa du informazio falta handia dela [14]. Hori dela eta, akuikulturan jatorria duten produktuen trazabilitate-maila altua eta osasun-kontrol altuak bateratuz, osasun-txartela deritzon erreminta garatuko da AKURA proiektuaren barruan; kontsumitzaileak, sakelako telefonoko aplikazio sinple baten bidez, lazun-lote konkretu baten informazio guztia aztertu ahalko luke QR kode bat bitarteko. Bertan, Europako Batasunak legez ezartzen duen informazioaz gain, kontsumitzaileentzat interesgarriak diren beste detaile batzuk ere agertuko lirateke: adibidez, arrainen jaiotzadata eta -tokia, elikadura mota, jaso izan ditzaketen tratamenduak, uraren kalitateak hazkuntzan zehar izan dituen gorabeherak, etab.

\subsubsection{Kalitatezko produktua merkaturatzea aurreiritziak baztertuz}

Euskal Herrian lazunak beti jan izan dira. Lazunak, portu eta itsasadarretako leku orotan ikusten dira gizakien hondakinak itsasora isurtzen diren lekuetan, sedimentuetako zein esekiduran dagoen materia organikoaz elikatzen dira eta. Horren ondorioz, euskal kostaldean eta ibai handien inguruan ospe txarra hartu duten espezieak dira, ustezko ur garbiagoetan (kostaldean) elikatzen diren beste indibiduoen edo antzerako espezieen (Liza aurata) mesedetan.

Horrela, tradizionalki, arroketako lazunak eta portuetan daudenak desberdindu dira, nahiz eta espezieak konfirmatzea erraza ez izan eta arrain 
horiek arrantzatu aurretik nondik ibili diren jakitea fidagarria ez izan. Edozein kasutan, gure kostaldean puntualki arrantzatu eta jan den arrain familia bat da, duten bizimoduarengatik ospe txarra izan arren. Aldiz, lazuna akuikultura produktu bat bilakatzen baldin bada, ur zikinetan bizitzeagatik duten ospe txarra murriztu edo ezabatuko da.

Osasun-txartelarekin bat datorren helburua honakoa litzateke: behin kalitatezko produktua ziurtatu ahal denean, produktu berri bat merkaturatzeak sozialki ekar ditzakeen beldurrak baztertzea, hau da, lazuna bezalako espezie batek ohituragatik gizartean sortzen dituen aurreiritzi negatiboak oker daudela frogatzea.

Lan honetan, lazunaren akuikultura berritzailearen oinarriak jartzeko aipatutako erronken artean bi landuko ditugu: 1) pentsuaren problematikari aurre egitea eta amaierako produktua aberastea, eta 2) ziklo biologikoa gatibutasunean ixtea. Lehenengo erronka jorratzeko, bi pentsu komertzial erabiliko dira lazuna bi akuikultura-sistemetan hazteko: amuarrainentzako pentsua (erauzketa-arrantzako produktuetako proteina/lipidoekin) eta tilapientzako pentsua (landare-karbohidratoetan oinarritua). Bigarren erronka burutzeko, zikloa ixteko beharrezkoak diren lehen pausoak emango dira, hau da, lazunaren errutearen indukzioa eta larbarioaren ezarpena.

\section{MATERIAL ETA METODOAK}

\subsection{Lazunaren hazkuntzaren azterketa bi pentsu komertzial erabiliz bi sistema mota ezberdinetan}

Esperimentuan erabiltzeko arrainak Cádizko Fauna Marina, S.L. enpresari erosi zaizkio, denbora falta dela eta, ezinezkoa izan delako indibiduo guztiak arrantzatzea. Arrain biziak garraio homologatu berezian ekarri dira Cádizetik Plentziara eta Mutrikura. Sistemaren ur-baldintza berrietara ohitzeko, hainbat orduko aklimatazioa ezarri da. Koarentenan mantendu dira arrainak hilabetez; hasierako hilkortasuna egonkortu den arren, guztira arrainen \% 10 hil da. Hilkortasun hori garraioan jasandako estresak edota jatorrizko gaixotasun zein urradurek eragindakoa dela ondorioztatu da.

Mugilidoen lote honetan hainbat espezie bereizten dira, \% 85 Chelon labrosus moduan identifikatu dira, \% 12 Liza aurata moduan eta \% $2 \mathrm{Mu}$ gil cephalus moduan. Arrainen batez besteko pisua $28 \mathrm{~g}$-koa da eta batez besteko luzera $13 \mathrm{~cm}-k o a$. Lotea bi zatitan banatu da eta bakoitza sistema mota batean kokatu da; bata irekia, non ur berria sartzen den etengabe, eta bestea itxia, non ura birzirkulazioan mantentzen den sistema barruan. Azken honetan, animalien ongizatea eta osasuna bermatzeko, uraren kalitateak ezarriko ditu ur-aldaketen maiztasuna. Parametro fisiko-kimikoak egunero neurtu dira; hauek hartzen dira baldintza estandartzat: $\mathrm{pH}=7,9$; 
oxigeno kontzentrazioa $>5 \mathrm{mg} / \mathrm{L}$; gazitasuna $\%$ o 36. Konposatu nitrogenatuak kit komertzial batekin neurtzen dira, eta, balio maximoetara heltzean, ur-aldaketa sakona (\%70-80) egiten da. Balio maximotzat hauek jo dira: $\mathrm{NH}_{4}=0,50 \mathrm{mg} / \mathrm{L} ; \mathrm{NO}_{2}=0,1 \mathrm{mg} / \mathrm{L} ; \mathrm{NO}_{3}=100 \mathrm{mg} / \mathrm{L}$. Sistema itxiaren eguneroko mantenuan uraren $\% 10$ aldatzen da gutxienez: esate baterako, urirteeren purgak, filtro mekanikoen erretrogarbiketa eta dekantazio-tankearen garbiketa egiterakoan.

Lote bakoitza 2 azpitaldetan banatu da eta pentsu mota desberdinekin elikatu dira 6 hilabeteetan zehar, emandako dosia kasu guztietan pisuaren $\%$ 2,5 izan delarik. Bi pentsuak komertzialak dira; tilapien eta amuarrainen hazkuntzan erabili ohi direnak, hain zuzen ere. Gantz, proteina eta karbohidrato kantitate desberdina dute formulazioan (ikusi 1. taula).

1. taula. Bi pentsu mota ezberdinen formulazioak.

\begin{tabular}{lccc}
\hline \multicolumn{1}{c}{ Pentsu mota } & Proteinak $(\%)$ & Gantzak $(\%)$ & Karbohidratoak $(\%)$ \\
\hline Tilapiarena & 35 & 6 & 45,0 \\
Amuarrainarena & 44 & 21 & 23,6 \\
\hline
\end{tabular}

Datu biometrikoak 3 hilabetetik behin jaso dira. Biometrietan, arrainen ongizate-egoera orokorra bermatzeaz gain, luzera eta pisua jaso dira; horrela, pentsuaren dosia ere doitzen joan da, \% 2,5ean mantentzeko. Bestalde, 45 egunetik behin, talde esperimentaleko 10 indibiduo disekzionatu dira, eta, datu biometrikoez gain, indize hepatosomatikoak (gibelaren pisua/arrainaren pisu osoa), analisi kimikoak eta histologikoak egiteko laginak jaso dira. Analisi histologikoetarako, gibela, hestea eta zakatzak disekzionatu dira eta nitrogeno likidoan izoztu dira. \% 4ko formaldehido kontzentrazioa duen itsas uretan finkatu dira 24 orduz. Etanol-kontzentrazio desberdineko serieetan deshidratatu eta xilenotik pasatu ondoren, parafinan murgildu dira. Behin parafina-blokeak solidotuta, mikrotomoz ebaki dira $5 \mu \mathrm{m}$-tan. Hematoxilina-eosinaz tindatu dira. Lipido neutroak aztertzeko laginak izoztu egin dira, eta, kriostatoan ebaki ondoren, Oil Red O histokimika bitartez tindatu dira. Analisi kimikoetarako, disekzioetan arrainen muskulua jaso da, profil lipidikoak lortzeko; lagin horiek izozkailuan mantendu dira hurrengo lanetan erabiltzeko.

\subsection{Ziklo biologikoa gatibutasunean itxi: errutearen indukzioa eta larbarioa}

Kardala LHII akuikultura eskolako instalakuntzetako Chelon labrosus espezieko lazun ugaltzaileak erabili dira errutea induzitzeko. Dentsitate oso baxuan dauden 13 indibiduo dira, 0,6-2,3 kg bitartekoak eta 3 urtetik go- 
rakoak. Banakako jarraipena egiteko, indibiduo bakoitzari txip bat txertatu zaio muskuluan. Hortik aurrera, ugaltzaile bakoitzaren datuekin egingo da lan, tratamendu espezifikoak egin ahal izateko. Ugaltzaileei zuzendutako pentsu komertzial bereziarekin elikatu dira, fabrikatzaileak gomendatzen duen dosian.

Irailean, MS222 konposatuarekin animaliak anestesiatu dira $100 \mathrm{mg} /$ 1-ko kontzentrazioarekin, eta gonaden garapenaren azterketak egin dira gonoduktuetatik plastikozko kanulak erabiliz (kanulazioa). Martxoan. hurrengo kanulazioa egin da; jadanik, gonadetan gametoak garatuta agertzen dira. Emeak bereizi, eta arrautzen tamaina aproposa izan denean lehenengo injekzio hormonala jarri zaie. Akuikulturan ohikoa den hormona luteinizantearen analogoa den hormona komertziala erabili da $15 \mu \mathrm{g} / \mathrm{kg}-\mathrm{ko} \mathrm{kon-}$ tzentrazioan. Gametoen tamainaren hazkuntza kanulazio bitartez bermatu denean bigarren hormona dosia ezarri zaie, kontzentrazio berean. 5 egunen buruan, errutea tankean bertan gertatzen da, eta arrautzak jaso dira haien flotagarritasunaz baliatuz. Zuzenean, inkubaziorako sistema ireki batean jarri dira arrautzak, 1,5 eta $20 \mu \mathrm{m}$-ko filtrazioarekin, aireazioarekin eta ura $18{ }^{\circ} \mathrm{C}$-an egonik. Arrautzak eklosionatu eta gero, arrainen garapena behatu da, fase desberdinak ezagutzeko eta malformaziorik dagoen detektatzeko helburuarekin. Errutearen kalitate minimoak bermatzeko, hilkortasun-mailak eta garapen larbarioaren gune kritikoen identifikazioa egiteko, egunero behaketa jarraituak egin dira. 70.000 bat arrautza jaso ziren, eta beste hainbeste ernaldu gabekoak; ernaltze-tasak, beraz, baxua dirudi. Handik bi egunera larbak jaio eta 3. egunetik aurrera (dph, days post haching) mikroalgekin eta aberastutako errotiferoekin (Brachionus plicatilis) elikatu dira egunero. Aurrerago, Artemia salina gehitu zaie dietara, errotiferoak murriztuz, eta, azkenik, granulazio txikiko pentsua gehitu da, elikagai bizidunak murriztuz harik eta dietatik kendu arte.

\section{EMAITZAK ETA EZTABAIDA}

\subsection{Lazunaren hazkuntzaren azterketa bi pentsu komertzial erabiliz bi sistema motatan}

Arrainen hilkortasuna oso baxua izan da $-\% 2$ baino baxuagoa, hain zuzen -, bai errezirkulazioan eta bai sistema irekian ere, lehenengo 6 hilabeteetan.

Esperimentua hasi zenetik 90. egunera, lazunak bai pisuan bai luzeran hazi dira, bi hazkuntza-sistema eta bi pentsu mota desberdinak erabiliz (ikusi 1. eta 2. irudiak). Hala ere, dieten konparaketari dagokionez, ez da desberdintasunik nabari lazunen hazkuntzan. Hazkuntza-sistema ezberdinetan hazitako lazunek ere ez dituzte luzera eta pisu ezberdinak aurkezten. 
Ager Ortiz Aginagalde, Nadia Conlledo Gorrotxategi, Xabier Lekube Iturrioz, Urtzi Izagirre Aramaiona

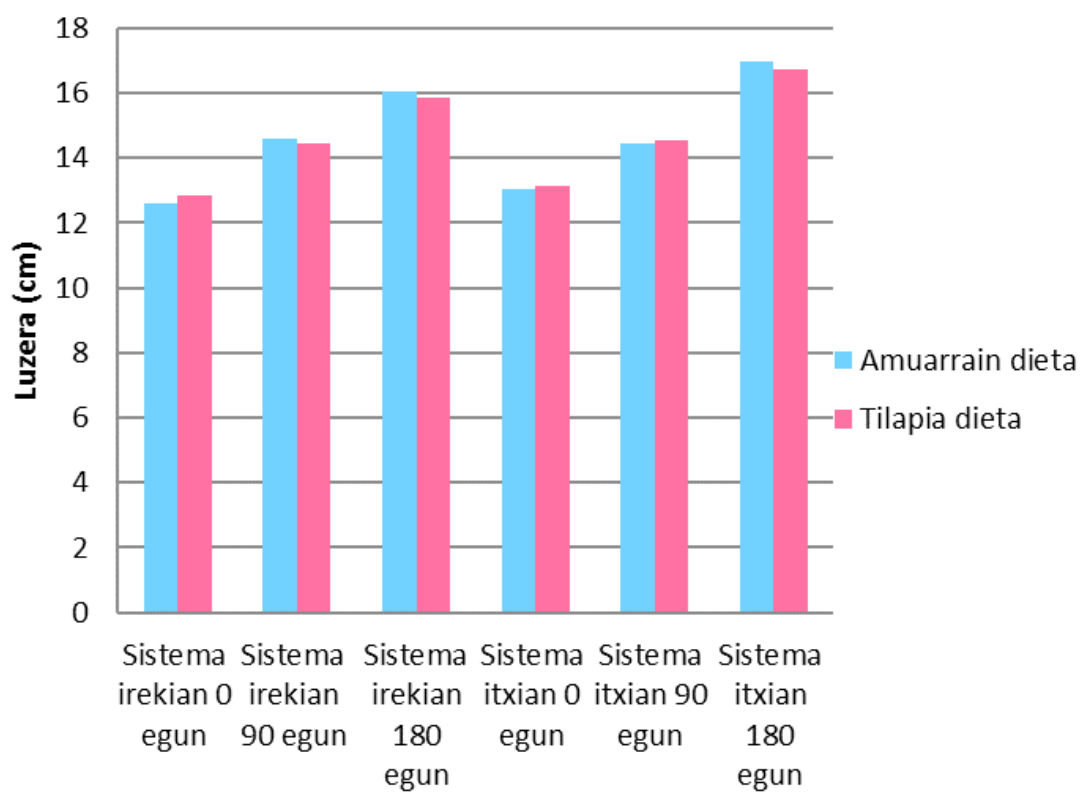

1. irudia. Lazunen pisua hazkuntza sistema eta dietaren arabera.

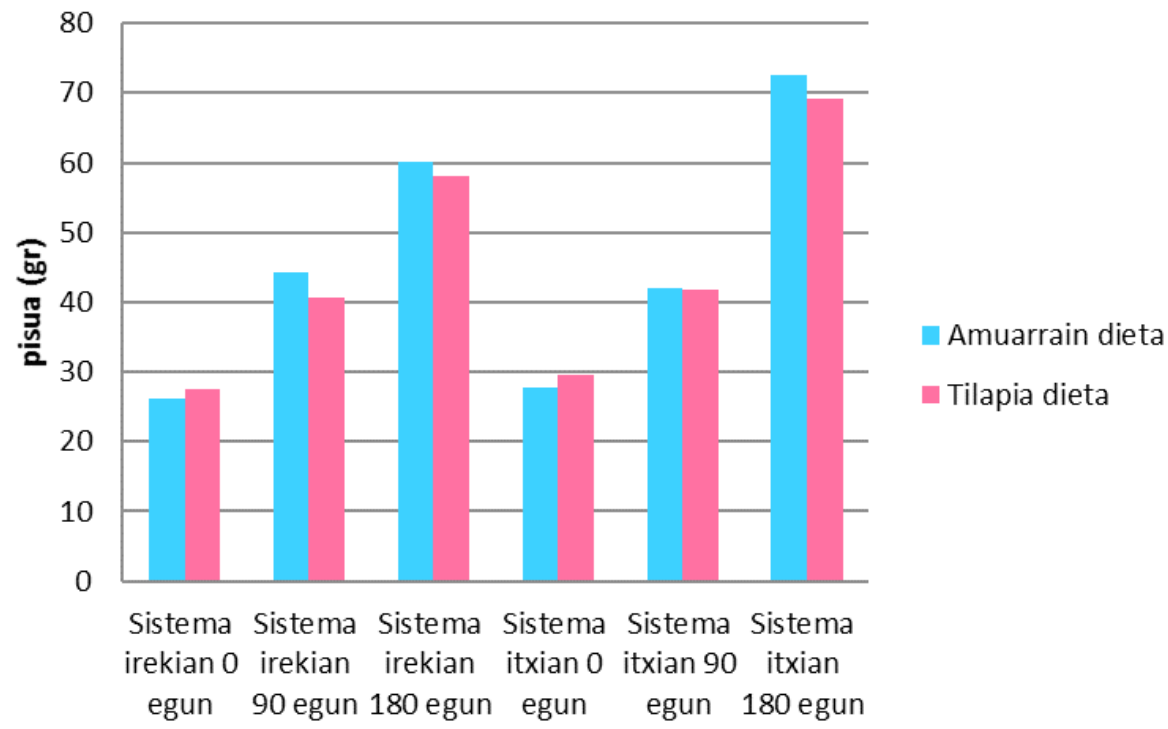

2. irudia. Lazunen luzera hazkuntza-sistemaren eta dietaren arabera. 
Lazunak bi pentsu motekin hazteko gai izan dira, eta sistema itxiak teorikoki izan ditzakeen desabantailek (oxigenoaren gorabeherak edota materia organiko ugariagoa...) ez dute lazunen hazkuntza moteldu; ez, behintzat, modu nabarmen batean. Jakina da, bide batez, elikaduraren konbertsio-tasan eta hazkuntzan kanpo-baldintzak ere erabakigarriak direla arrainaren adinaz gain [15], eta, beraz, posiblea da sistema itxian izaten diren baldintzek eragin negatiboa izatea indize horietan. Pentsuaren osagarriei dagokienez, tilapia pentsua karbohidrato askoz, lipido gutxiz eta amuarrain-pentsua baino proteina gutxiagoz osatuta dago; beraz, proteinaren aprobetxamenduaren aldetik, eta lipido kantitate gutxiagoko erabileraren aldetik, oso interesgarria da; bereziki, jasangarritasunaren bidean kokatzen bagara. Gainera, Tilapiaren pentsua oinarri gisa erabiliz gero, proteina eta lipido gutxiago dituenez, lazunen produkzioaren kostua asko merkatuko litzateke; hain zuzen ere bi nutriente horiek garestitzen dituztelako pentsuak.

Hala ere, karbohidratoekin bezala, badirudi balitzatekeela tarterik pentsu birformulatu batean proteina kopurua zerbait igotzeko (betiere amuarrainarena baino baxuago mantenduz) are absortzio-tasa egokiagoekin, prozesua oztopatzen duten lipidorik gabe, baina hipotesi horiek hurrengo lanetan landuko dira.

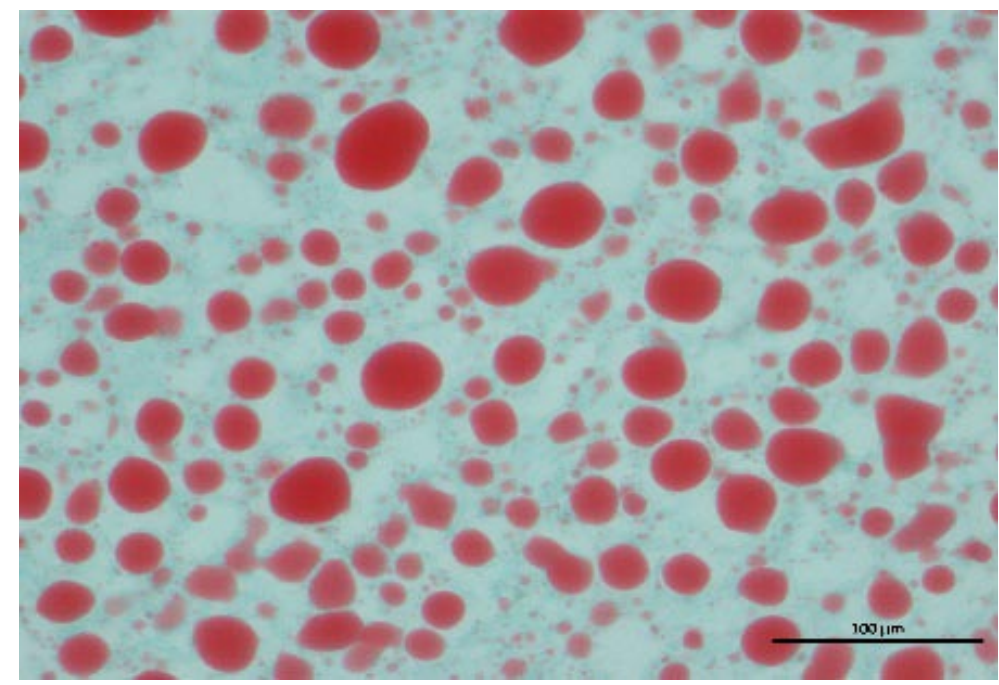

3. irudia. Lazunen gibelaren ebakin histologikoa bakuolaz betea.

Disekzioetan jasotako arrain-organoak histologikoki aztertu direnean, talde esperimentalen artean ez da desberdintasunik ikusi muskulu eta zakatzen kasuan. Gibelean zein hesteetan metatutako gantz kantitatean dago gakoa. Gibelaren bakuolizazioa bi dietetan nabarmena da (ikusi 3. irudia), 
baina tilapiaren kasuan pixka bat altuagoa. Hori bat dator indize hepatosomatikoaren emaitzekin (ikusi 4. irudia), 2 sistemetan altuagoa baita tilapiaren dietaren kasuan. Indize hepatosomatikoa altua izatea ere, karbohidrato altuko dieten erabilerarekin erlazionatuta dago [16]; hori bat dator tilapiaren dietaren konposizioarekin. Indize hepatosomatikoen balioak bestelako lanetan espezie orojaleetan ikusitakoekin bat datoz [16]. Hala ere, denboran zehar jaisteko joera dauka, eta hori erlaziona dezakegu hazkuntza egoki baten egonkortze fisiologiko batekin.

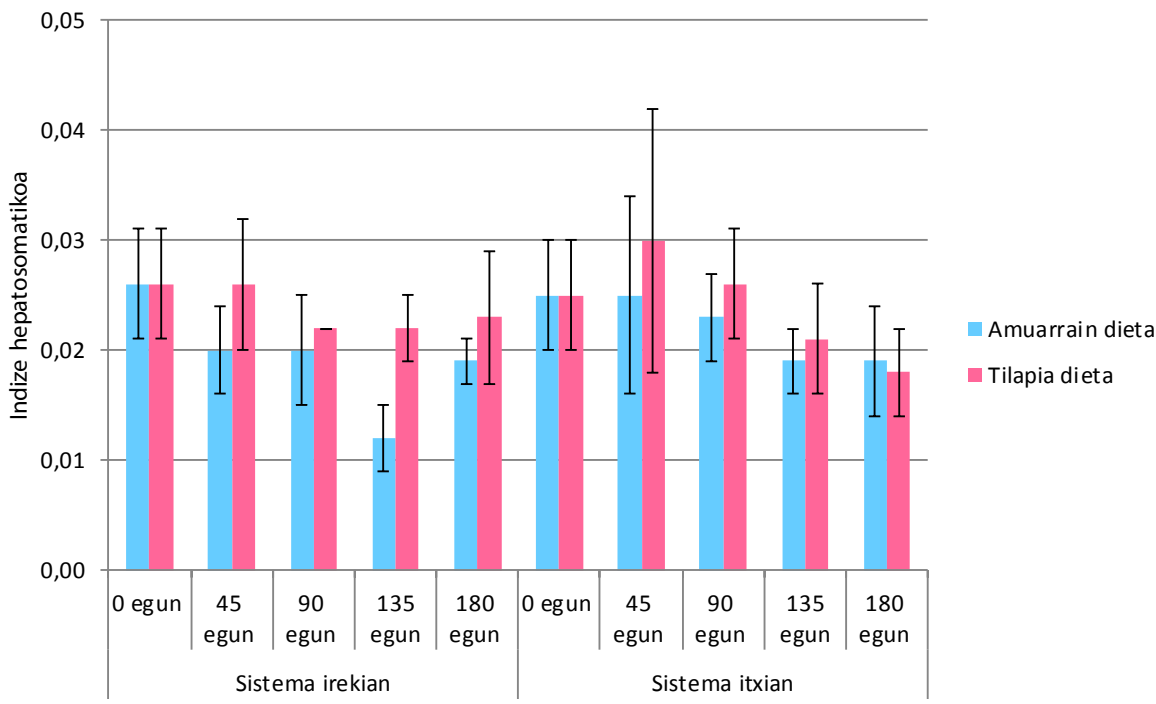

4. irudia. Lazunen indize hepatosomatikoaren bilakaera hazkuntza-sistemaren eta dietaren arabera.

Gibela handiagoa da, lipidoa metatzen delako horretan, eta hori hepatozitoak gantz-azidoak oxidatzeko ahalmen maximoa gainditzen denean gertatzen da [17], baina ez da hasiera batean espero zitekeena, tilapia-pentsuak gantz gutxiago duelako (\% 6) amuarrainarenak baino (\% 23). Badirudi karbohidrato hori guztia sobera dagoela tilapiaren dietan, eta gibelean metatzen dela lipido bezala energia-erreserba gisa. Horregatik, lehen planteatutako ideiekin jarraituta, etorkizuneko dietan proteina kopurua igo ahal dela ondoriozta genezake, energia metatuta badago proteinen prozesamenduan lagundu ahal duelako. Proteina-maila altuagoa duten dietek hepatozitoen estruktura mantentzen laguntzen dute [18].

Hesteetan metatutako gantza, ordea, askoz nabarmenagoa da amuarrain-dietaren kasuan (ikusi 5. irudia), hestearen epitelio eta ehun konektiboan zehar agertzen delarik. Izan ere, amuarrain-dietan lipido kantitate altua zu- 
zenki metatzen dela dirudi, bai gibelean eta bai hestean ere. Badirudi lazunen hesteetako profil entzimatikoa adinarekin aldatuz doala [19], elikadura-ohitura orojaleagoetatik belarjaleagoetarako tendentzia erakutsiz, eta, oro har, lazunek lipasa-maila oso baxua dutela ikusi da, eta, beraz, gantzak digeritzeko ahalmen txikia dutela.

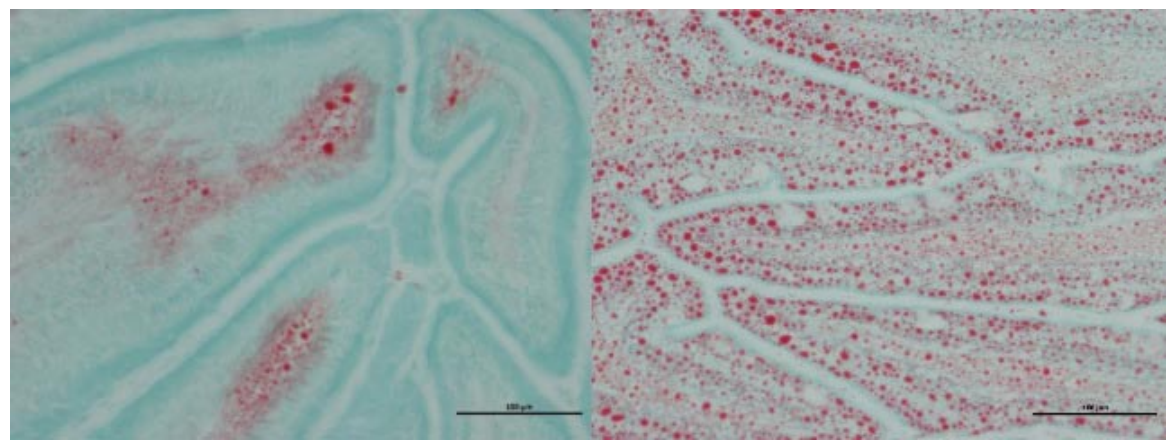

5. irudia. a) Lazunaren hestea tilapia-dietarekin. b) Lazunaren hestea amuarraindietarekin.

Horrek gehiegizko gantza metatzea ekarriko luke; ondorioz, beste hainbat elikagairen xurgapena oztopatu eta konbertsio-tasa handiagotuko litzateke [20].

Hori horrela izanda, etorkizunerako lazunen pentsuen formulazioak landare-jatorriko karbohidratoaren oinarri bat izan beharko luke, jatorri jasangarria eta kalitate altua izango duten proteina eta lipido gutxi batzuk gehituz betiere (batez ere omega-3 familiakoak). Izan ere, kalitatezko lipidoen inguruan AKURA proiektuak ere badihardu. Hasierako fasean dagoen esperimentu honetan, Nannochloropsis gaditana alga mikroskopikoa, liofilizatu eta birrindu ondoren, tilapiarentzat erabiltzen den birrindutako pentsuari gehituko zaio, kontzentrazio ezberdinetan. Alga-espezie hori aukeratu da bere bide metabolikoetan sortzen dituen konposatu interesgarrien kopuru altua dela eta [11]. Badirudi omega-3a eta gisako gantz-azidoak asko eraldatu gabe meta daitezkeela lazunen ehunetan, eta horrek efektu baikorra izan dezakeela gizakiengan, azken kontsumitzaileak baitira.

\subsection{Ziklo biologikoa gatibutasunean itxi: errutearen indukzioa eta larbarioa}

70.000 bat arrautza jaso ziren, eta beste hainbeste, ernaldu gabekoak; ernaltze-tasak, beraz, baxua dirudi. Handik bi egunera larbak jaio, eta 3. egunetik aurrera (dph, days post haching) mikroalgekin aberastutako errotiferoekin (Brachionus plicatilis) elikatu ziren egunero. Aurrerago Ar- 
temia salina gehitu zitzaion dietara, errotiferoak murriztuz, eta, azkenik, ale-tamaina txikiko pentsua gehitu zen, elikagai bizidunak murriztuz harik eta dietatik kendu arte.

Fase horretan larben kantitatea kontatzeko baliabideak falta ziren arren, hilkortasun-maila altuena noiz izaten den zehaztea lortu zen. Oro har, hilkortasun-tasa moderatuak egon dira garapen-fase gehienetan $(<\% 15)$. Fase kritiko bat identifikatu da biteloa guztiz agortzen den unean (12-21 dph) (ikusi 6. irudia); fase honetan, $>\%$ 40ko hilkortasun-tasa behatu da.

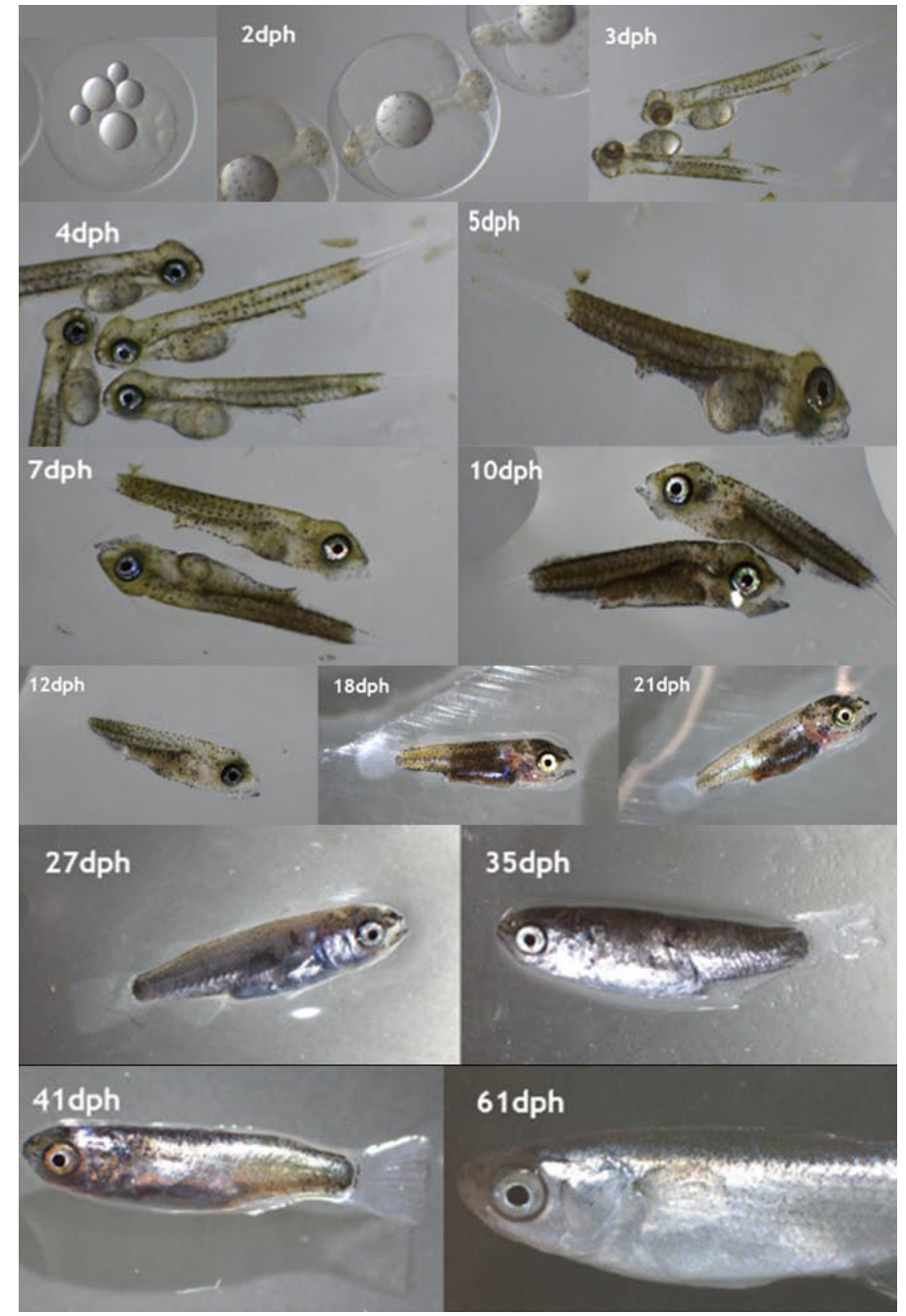

6. irudia. Lazun-larben garapena luparen bidez ateratako argazkietan. Enbrioiak 1,2 mm. 
Nutrizio-behar bereziak izateak justifikatuko luke hilkortasuna fase horretan. Hala ere, fase kritikoa pasatu ondoren hilkortasuna $<\% 15$ izan da. Proiektua bukatu aurretik, errutearen kalitatea ezartzeko testak egingo dira hurrengo errute-denboraldian, hilkortasun-tasarekin korrelazio bat ezartzeko helburuarekin.

Espero den bezala, hazkuntza-tasa altua erakusten dute; alegia, azken bost asteetan batez besteko pisua bost aldiz handitu da (ikusi 6 . irudia eta 2. taula) eta, bereziki azken hilabetean, pentsu-dosia handitu behar izan da, gose asegaitza erakusten dutelako.

2. taula. Lazun-larben hazkuntzaren bilakaera.

\begin{tabular}{rcc}
\hline Denbora & Luzera $(\mathrm{cm})$ & Pisua $(\mathrm{g})$ \\
\hline 9 aste & 2,70 & 0,48 \\
14 aste & 5,68 & 2,40 \\
\hline
\end{tabular}

\section{ONDORIOAK}

Kontuan hartuta lazuna akuikulturan espezie berritzailea dela eta datu falta nabarmena dagoela, lan honen ekarpen garrantzitsuena da espezie horren inguruko ezagutza lortu izana. Lazunak modu arrakastatsuan mantendu eta hazi dira bi akuikultura-sistema desberdinetan eta bi pentsu komertzial desberdinekin. Hazkuntza-tasa antzekoekin, esan dezakegu Tilapia-pentsua aproposagoa suertatu ahal dela proteina-asimilazio egoki bat erakusten duelako. Bestalde, gatibutasunean arrautzak eskuratzea lorpen handitzat jo dezakegu, eta ezinbesteko aurrerapausoa da akuikulturan oinarrizkoa den bizi zikloa ixteko.

Hemendik aurrerako helburua da arrainkumeen hazkuntza eta garapenaren jarraipena egitea, hazkuntza-tasak lortuz eta azpitalde esperimentalak ezarriz, banakako parametro desberdinen aldakortasunak hazkuntzan duen efektua detektatzeko. Lortu den errutetik hurrengo belaunaldi bat izatea ere espero da, bizi-zikloaren itxiera bermatzeko. Bestaldetik, lazunaren akuikultura jasangarria ezartzeko, oraindik ikerketa sakonak beharrezkoak dira pentsuen formulazio berriekin, eta tenperatura eta dentsitate optimoen bilaketarekin.

\section{ESKER ONAK}

Eusko Jaurlaritzako Ekonomiaren Garapen eta Azpiegitura saileko Arrantza eta Akuikultura zuzendaritzari, Itsas eta Arrantzarako Europako Funtsa bitarteko AKURA proiektuaren finantziaziogatik (Ref. 33-2017-00250). 
Ager Ortiz Aginagalde, Nadia Conlledo Gorrotxategi,

Xabier Lekube Iturrioz, Urtzi Izagirre Aramaiona

\section{BIBLIOGRAFIA}

[1] FAO, 2018, «The State of World Fisheries and Aquaculture 2018 - Meeting the sustainable development goals» Rome. Licence: CC BY-NC-SA 3.0 IGO.

[1] FAO, 1997, «Technical guidelines for responsable fisheries» Chapter 5, Aquaculture development.

[2] APROMAR, 2019, «La acuicultura en España 2019»

[3] «DIVERSIFY» PROJECT, 2013-2018, «Exploring the biological and socioeconomic potential of new/emerging candidate fish species for expansion of the European aquaculture industry» https://www.»Diversify»fish.eu

[4] EUSKO JAURLARITZA, 2014, «Akuikulturaren Garapenerako Plan Estrategikoa 2014-2020»9-10.

[5] CROSETTI, D., BLABER, S., 2016, «Biology, Ecology and Culture of Grey Mullet (Mugilidae)» Chapter 9.

[6] YUFERA, M., \& ARIAS, A.M., 2010, « Traditional polyculture in «esteros» in the Bay of Cádiz (Spain). Hopes and expectancies for the prevalence of a unique activity in Europe» Aqua Eur, 35(3) , 22-25.

[7] IACONISI, V., MARONO, S., GIULIANA PARISI, G., GASCO, L., GENOVESE, L., MARICCHIOLO, G., BOVERA, F., PICCOLO, G., 2017, «Dietary inclusion of Tenebrio molitor larvae meal: Effects on growth performance and final quality treats of blackspot sea bream (Pagellus bogaraveo)» Aquaculture, 476, 49-58.

[8] MAGALHÃES, R., SÁNCHEZ-LÓPEZ, A., SILVA LEAL, R., MARTÍNEZ-LLORENS, S., OLIVA-TELES, A., PERES, H., 2017, «Black soldier fly (Hermetia illucens) pre-pupae meal as a fish meal replacement in diets for European seabass (Dicentrarchus labrax)» Aquaculture, 476, 79-85.

[9] BISWAS, A., ARAKI, H., SAKATA, T., NAKAMORI, T., TAKII, K., 2019, «Optimum fish meal replacement by soy protein concentrate from soymilk and phytase supplementation in diet of red sea bream, Pagrus major» Aquaculture, 506, 51-59.

[10] QIAO, H., HU, D., MA, J., WANG, X., WU, H., WANG, J., 2019, «Feeding effects of the microalga Nannochloropsis sp. on juvenile turbot (Scophthalmus maximus L.)» Algal Research, 41, 101540.

[11] ABDUL WAHAB, M.A., DE NYS, R., WHALAN, S., 2012, «Closing the lifecycle for the sustainable aquaculture of the bath sponge Coscinoderma matthewsi» Aquaculture, 324-325, 281-289.

[12] CATAUDELla, S., MASSA, F., RAMPACCI, M., \& CROSETTI, D., 1988), «Artificial reproductionand larval rearing of the Thick Lipped Mullet (Chelon labrosus)» J. Appl. Ichthyol, 4, 130-139.

[13] REIG, L., ESCOBAR, C., CARRASSÓN, M., CONSTENLA, M., GIL, J. M., PADRÓS, F., PIFERRER, F., FLOS, R., 2019, «Aquaculture perceptions in the Barcelona metropolitan area from fish and seafood wholesalers, fishmongers, and consumers» Aquaculture, 510, 256-266. 
[14] HANDELAND, S.O., IMSLAND, A.K., \& STEFANSSON, S.O., 2008, «The effect of temperature and fish size on growth, feed intake, food conversion efficiency and stomach evacuation rate of Atlantic salmon post-smolts» Aquaculture, 283 (1), 36-42.

[15] JOVER CERDÁ, M., L. PÉREZ IGUALADA, L. ZARAGOZA y J. FERNÁNDEZ CARMONA, 1998, «Crecimiento de tilapias (Oreochromis niloticus, 1.) con piensos extrusionados de diferente nivel proteico» Archivos de zootecnia vol. 47, núm. 177, p. 11-20.

[16] CABALLERO, M.J., IZQUIERDO, M.S., KJORSVIK, E., FERNANDEZ, A.J., \& ROSENLUND, G. , 2004, «Histological alterations in the liver of sea bream, Sparus aurata L., caused by short- or long-term feeding with vegetable oils. Recovery of normal morphology after feeding fish oil as the sole lipid source» Journal of Fish Diseases, 27, 531-541.

[17] FOUNTOULAKI, E., GRIGORAKIS, K., KOUNNA, C., RIGOS, G., PAPANDROULAKIS, N., DIAKOGEORGAKIS, J., \& KOKOU FOTINI, 2017, «Growth performance and product quality of Meagre 27 (Argyrosomus regius) fed diets of different protein/lipid levels at industrial scale» Italian Journal of Animal Science, 16(4), 685-694.

[18] PUJANTE, I. M., DIAZ-LOPEZ, M., MANCERA, J. M., \& MOYANO, F. J., 2017, «Characterization of digestive enzymes protease and alpha-amylase activities in the thick-lipped grey mullet (Chelon labrosus, Risso 1827)». Aquaculture Research, 48, 367-376.https://doi.org/doi:10.1111/are.13038

[19] DUNCAN, D., 2019, «Diferential growth and aspects of the health of Chelon labrosus (Risso, 1827) fed on commercial trout and tilapia feeds in Open Flow and a Recirculatory Aquaculture System» (Master's thesis, Ghent University, Ghent, Belgium). 